\title{
Ecological and biological studies on the Nile tilapia Oreochromis niloticus along different sites of lake Burullus
}

\section{Khalid H. Zaghloul ${ }^{1}$, Wafaa S. Hasheesh ${ }^{2}$, Iman A. Zahran ${ }^{3}$ and Mohamed-Assem S. Marie ${ }^{2}$}

\author{
1- Zoology Department, Faculty of Science / El-Fayoum University. \\ 2- Zoology Department, Faculty of Science / Cairo University. \\ 3- Cairo central centre lab. for Environmental Monitoring, Egyptian \\ Environmental Affairs Agency.
}

\begin{abstract}
T ake Burullus represents an economically important lake in Egypt , due to its $\amalg$ rich fishery resources. Unfortunately, the lake is exposed to many kinds of chemical and biological pollutants in addition to the remains of agricultural and wastes that are disposed into it. So, the aim of the present study was compare the quality of water samples collected from three different sites along lake Burullus; a site of the lake in contact with the Mediterranean sea called ElBoughaz inlet, western sector of the lake where agricultural drainage discharged and eastern sector where agricultural and industrial effluents.

Water quality of samples collected from the different studied sites along the lake showed highly significant $(\mathrm{P}<0.01)$ differences with the highest values in the dissolved oxygen content and salinity at El-Boughaz inlet. However, water samples collected from the eastern and western sectors of the lake showed highly significant $(\mathrm{P}<0.01)$ increase in ammonia, nitrite, $\mathrm{Cu}, \mathrm{Zn}$ and $\mathrm{Mn}$ but insignificant $(\mathrm{P}>0.05) \mathrm{Pb}$ concentration. Bioaccumulation of either of the studied heavy metals in gills, liver, kidneys and muscles of the Nile tilapia; Oreochromis niloticus collected from the eastern and western sectors of the lake was much higher than that of fish collected from El-Boughaz inlet. Moreover, histopathological sections showed clear damage of gills, liver and kidney of fish collected from eastern and western sectors of the lake.

Furthermore, Oreochromis niloticus collected from eastern and western sectors of the lake had lower condition factor values, hepatosomatic index, RBCs, Hb, Ht, serum total protein and total lipids but higher liver water contents, WBCs, MCV, MCH, serum glucose, AST, ALT, creatinine and uric acid.

The obtained results also revealed that the meat quality of the collected fish from El-Boughaz inlet was more superior than those of fish collected from the eastern and western sectors of the lake.
\end{abstract}

Key words: lake Burullus, Oreochromis niloticus, industrial and agricultural effluents, Heavy metals 


\section{INTRODUCTION}

Lake Burullus is the central of five principal coastal lagoons of northern Egypt. To the east are lake Manzala and Bardawil, to the west are lake Idku and lake Maryut. It is a part of the governorate of Kafr El-Sheikh in the northern part of the delta that lies between the two branches of the Nile. Lake Burullus is separated from the sea (the Mediterranean sea) by a $65 \mathrm{~km}$ long sand bar, the middle section of the bar is narrow and is cut by an inlet (Boughaz) that connects the sea and the lake. The lake comprises a body of water $\left(460 \mathrm{~km}^{2}\right)$. The area decreased during the last 50 years due to land reclamation of its southern stretches (NWRP, 2000). Moreover, annual fish production of lake Burullus is around 55.000 tons; which is about $40 \%$ of the northern lakes and $13.5 \%$ of the national fish production. (NWRP, 2000).

In the last few years however changes in water quality resulted from the high load of effluents discharged directly into the lake (Elghobashy et al., 2001). Over the last years, a considerable population growth has taken place, accompanied by a steep increase in urbanization, industrial and agriculture land use. This has entailed a tremendous increase in discharge of a wide diversity of pollutants to receiving water bodies and has caused undesirable effects on the different components of the aquatic environment and on fisheries (FAO, 1992; Elghobashy et al., 2001 and Zaghloul et al., 2005). Furthermore, modern agricultural activities have introduced several polluting substances such as organic matter, chemical fertilizers, insecticides, herbicides, ect., into the river Nile and drainage system. Drainage water is therefore contaminated with salts, agricultural chemicals (pesticides and heavy metals) and other pollutants as pathogens from domestic sewage and industrial discharge (Gad, 2005).

Recently the aquatic organisms are used as indicators of trace metals pollution. Heavy metal concentrations are extremely variable in various marine and fresh water organisms depending on the geochemical background, the level of pollution in a given area, and fish activity (Mansour and Sidky, 2002; Zaghloul et al., 2005; Carvalho and Fernands, 2006 and Yilmaz et al., 2007). Bioaccumulatiom of heavy metals in fish may critically influence the growth rate , physiological and biochemical status and consequently the meat quality of fish (El-Naggar et al., 1998 and Haggag et al,. 1999). Moreover, it has been observed that through biological amplification, some aquatic organisms may concentrate metals present in low concentration in the environment to levels that exceed standards are harmful to organisms. Fish likewise other aquatic organisms, are greatly affected with chemical pollutants present in the ecosystem (Salama, 1995). It is recommended that the developed histopathological changes in fish can be used as biondicators for environmental pollution (Gaber, 2003).

So the aim of the present study is to compare the quality of water samples collected from three different sites along El-Burullus lake, as well as to investigate some physiological, and histopathological changes in the Nile tilapia; Oreochromis niloticus collected from these sites. 


\section{MATERIALS AND METHODS}

The present work was carried out on lake water and Nile tilapia fish; Oreochromis niloticus where samples collected directly from different sites along El-Burullus lake (map 1). The studied sites were chosen along El-Burullus lake, since taking into consideration some factors affecting on these sites, which lies in the discharge zone, where a number of drains (industrial and agricultural) discharge their outlet directly into the lake leading to change the water quality.

\section{Description of the studied sites:}

Three sampling sites were chosen at the eastern and western sectors of the lake, in addition to a site connect the lake with the Mediterranean sea.

Site (1) : Near the source of sea water (the Mediterranean sea) called ElBoughaz inlet.

Site (2) : The western sector near the agricultural effluents, where a drainage canal called El- Hoxa is found.

Site (3) : The eastern sector near the industrial and agricultural effluents of a drain near a region called El-Belak.

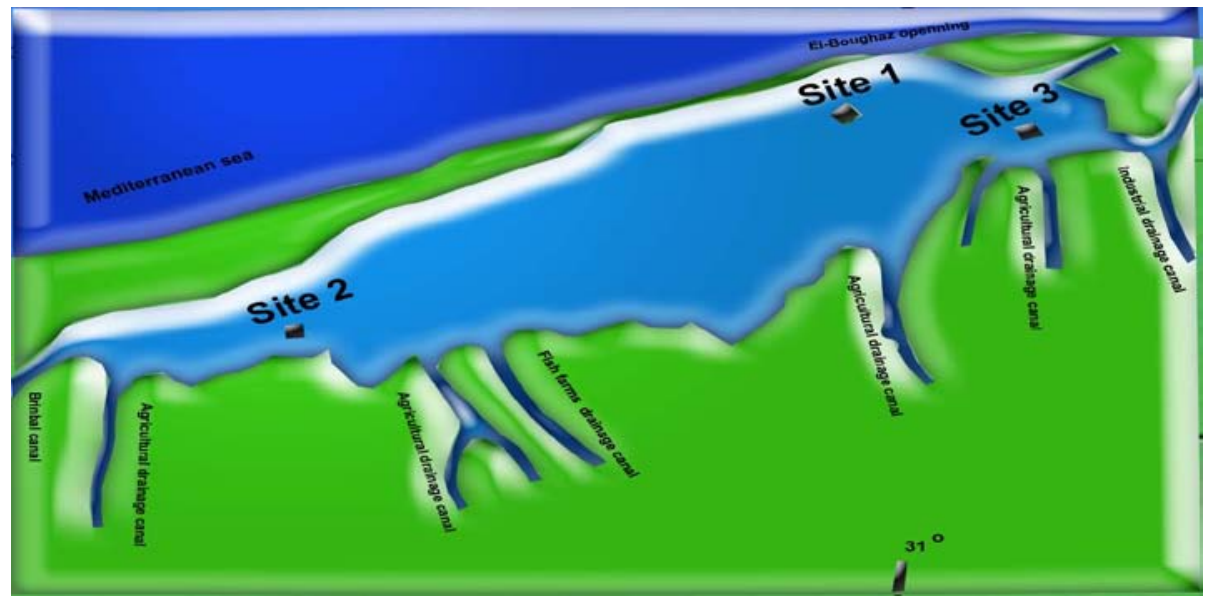

Map (1): Map showing studied sites of samples collection along El- Burullus Lake

\section{Water and fish sampling:}

Water and fish samples (15 samples) were collected from the different studied sites along El-Burullus lake every 15 days for a period from June to August, 2005 for studying the following criteria.

\section{Analytical techniques:}

(1) Water analyses

Water samples collected from the different studied sites were analyzed for water tempreature, oxygen content, $\mathrm{pH}$, water hardness, total alkalinity, ammonia, nitrite and electric conductivity according to the method described by American Public Health Association standard methods (APHA, 1995). Heavy 
metal concentrations in water were determined by atomic absorption spectrophotometry (Perkin Elmer, 2280) .Metals measured in this study were lead, copper, zinc and manganese.

\section{(2) Growth parameters:}

Body weight was recorded to the nearest gram and the total body length was measured to the nearest $0.1 \mathrm{~cm}$ individually for Oreochromis niloticus collected from the different studied sites along El-Burullus lake.

a) Condition factor $(\mathrm{k})$ :

' $K$ ' factor was calculated for individual fish from the formula recommended by Schreck and Moyle (1990) as follows :

$$
\mathbf{K}=\frac{\mathbf{W}}{\mathbf{L}^{3}} \mathbf{- - -} \mathbf{X} 100
$$

Where

$\mathrm{W}$ : is the wet weight in $\mathrm{g}$.

$\mathrm{L}$ : is the total length in $\mathrm{cm}$.

b) Hepatosomatic index (HSI) was calculated as liver percentage to whole body wet weight according to Schreck and Molye (1990) as follows:

\section{H S I = - ------------------------ X 100 \\ Total fish weight \\ (3) Blood sampling and Examination:}

Blood samples were withdrawn from the arterial caudalis where the needle was run quite deep as much as possible through the middle line just behind the anal fin in a dorso-cranial direction by drawing the needle gentely backward, blood is usually sucked into the syringes. The addition of sodium citrate to blood samples is the most satisfactory anticoagulant since heparine and oxalate were found to be unsatisfactory in completely preventing coagulation (Hesser,1960 ). The blood samples were immediately prepared for the following determinations:

i) Red and white blood cell counts:

Total number of erythrocytes (RBCs) and leucocytes (WBCs) were counted using Neubauer Haemocytometer.

ii) Haemoglobin content:

Haemoglobin was estimated in blood by using cyanmethemoglobin method described by Van Kampen and Zijlstra (1961).

iii) Haematocrite value (Ht \%):

Haematocrite value (Ht \%) was determined by using small haematocrit graduated tubes and haematocrite centrifuge at 3000 r.p.m.for 10 minutes.

iv) Calculated blood parameters:-

Blood indices were calculated according to Gupta (1977) as follows:

a)- Mean corpuscular volume $\left(\mu \mathrm{m}^{3} /\right.$ cell $)$ 


$$
\text { MCV = }
$$

b) - Mean corpuscular haemoglobin (pg/cell)

$$
\text { MCH }=\frac{\text { Hb }(\mathrm{gm} / 100 \mathrm{ml} \text { blood })}{\text { R.B.Cs }\left(\mathrm{million} / \mathrm{mm}^{3}\right)}
$$

c) - Mean corpuscular haemoglobin concentration (g / $100 \mathrm{ml}$ )

$$
\text { МСHC }=\frac{\text { Hb }(\mathrm{gm} / 100 \mathrm{ml} \text { blood })}{\text { Ht (\%) }}
$$

\section{(4)- Biochemical analyses:-}

\section{(a) Serum analyses:}

The collected Blood samples were centrifuged to get sera for the following analyses:

(I) Serum glucose:

Serum glucose was measured by using the GOD-PAP method (enzymatic colorimetric method) according to Trinder (1969) using Boehringr Mannheim kits.

(II) Serum total protein:

Serum total protein was determined by Biuret test (King and Wootton, 1959).

(III) Serum total lipids:

Serum total lipids concentration was determined colorimetrically by sulphovanillin reaction according to Schmit (1964).

(IV) Serum (AST, E.N. 2.6.1.1) and (ALT, E.N. 2.6.1.2)

Serum aspartate amino transferase ( AST ) and alanine amino transferase (ALT ) activities were determined colorimetrically using transferases kits according to method described by Reitmans and Frankel (1957).

(V) Serum creatinine:

Serum creatinine was measured using colorimertric method described by Henry (1974).

(VI) Serum uric acid:

Serum uric acid was determined using enzymatic reaction according to Barham and Trinder (1972). 
(b) Liver analyses:

(I) determination of liver water content:

Liver samples were rapidly transferred to a weighting bottles and accurately weighted then placed in drying oven at $60{ }^{\circ} \mathrm{C}$ overnight then raised to $105^{\circ} \mathrm{C}$ for 6 hours according to Sidwell et al.( 1970 ).

(C) Muscle analyses:

(I) Muscle water content:

Muscle water content was determined according to Sidwell et al., (1970).

(II) Muscle total protein:

Muscle total protein was determined using the semi -microkjeldahl as reported by Josyln (1950).

(III) Muscle total lipids:

Muscle total lipids were determined by the standard method reported by AOAC (1980).

(IV) Ash:

Muscle ash was determined by burning the samples in muffle furnace for 16 hours at $550{ }^{\circ} \mathrm{C}$ as reported by Sidwell et al. (1970).

(5) Residual Heavy metal concentrations in some selected organs:

Residual heavy metals (lead, copper, manganese and zinc) were detected in gills, kidney, liver and muscle according to APHA (1995) then measured using atomic absorption spectrophotometry (Perkin Elmer ,2280). (6) Histopathological studies:

Gills, liver and kidney of Nile tilapia; Oreochromis niloticus , collected from different studied sites along El-Burullus lake were fixed in neutralized formalin, dehydrated, embedded in paraffin wax and sectioned at $5 \mu \mathrm{m}$ then stained with Haematoxylin and Eosin according to Carleton et al. (1967).

\section{(7) Statistical analyses:}

The results were statistically analyzed using analysis of variance and followed by Duncan's multiple range test to determine difference in means (SAS, 2000).

\section{RESULTS AND DISCUSSION}

Water quality of the aquatic habitat is considered the main factor controlling the state of health and disease in both cultured and wild fish. Nowadays, deterioration of the natural water resources conditions by the action of effluents discharged from various industries affect the quality and quantity of the fish (Salah El-Deen et al., 1999; Elghobashy et al., 2001 and Zaghloul et al., 2005).

The present field investigations included the study of water quality and fish samples collected directly from three sites along El-Burullus lake. It also concerned with the study of some physiological and biochemical parameters of fish reared in the different studied sites. 
Physicochemical properties of water samples collected from the locations of the different sites of El-Burullus lake are illustrated in Table (1).

Table (1): Water quality criteria of the different studied sites along lake Burullus.

\begin{tabular}{|c|c|c|c|c|c|c|c|}
\hline $\begin{array}{l}\text { Parders } \\
\text { Studied SM }\end{array}$ & $\begin{array}{c}\text { Dissolved } \\
\text { oxygen } \\
\text { (mg/l) }\end{array}$ & $\mathrm{pH}$ & $\begin{array}{c}\text { Total } \\
\text { Hardness } \\
\left(\text { asCaCO }_{3}\right) \\
\text { mg/l }\end{array}$ & $\begin{array}{c}\text { Total } \\
\text { alkalinity } \\
\left(\text { as } \mathrm{CaCO}_{3}\right) \\
\mathrm{mg} / \mathrm{l}\end{array}$ & $\begin{array}{l}\text { Salinity } \\
\text { (g/l) }\end{array}$ & $\begin{array}{c}\mathrm{NH}_{3} \\
(\mathrm{mg} / \mathrm{l})\end{array}$ & $\begin{array}{c}\mathrm{NO}_{2} \\
(\mathrm{mg} / \mathrm{l})\end{array}$ \\
\hline $\begin{array}{c}\text { Site } 1 \\
\text { El-Boughaz } \\
\text { inlet }\end{array}$ & $\begin{array}{c}7.5 \\
\pm 0.21 \\
\quad \mathrm{~A}\end{array}$ & $\begin{array}{c}7.48 \\
\pm 0.06 \\
\mathrm{~A} / \mathrm{B}\end{array}$ & $\begin{array}{c}361 \\
\pm 3.14 \\
A\end{array}$ & $\begin{array}{c}243 \\
\pm 3.10 \\
\mathrm{~A}\end{array}$ & $\begin{array}{c}3.85 \\
\pm 0.06 \\
\text { A }\end{array}$ & $\begin{array}{c}0.065 \\
\pm 0.004 \\
\quad \mathrm{C}\end{array}$ & $\begin{array}{c}0.20 \\
\pm 0.03 \\
\text { B }\end{array}$ \\
\hline $\begin{array}{c}\text { Site } 2 \\
\text { Western sector } \\
\text { (Agricultural } \\
\text { effluents) }\end{array}$ & $\begin{array}{c}5.58 \\
\pm 0.19 \\
\mathrm{C}\end{array}$ & $\begin{array}{c}7.66 \\
\pm 0.07 \\
\text { A }\end{array}$ & $\begin{array}{c}314 \\
\pm 4.49 \\
\mathrm{C}\end{array}$ & $\begin{array}{c}224 \\
\pm 3.63 \\
\text { B }\end{array}$ & $\begin{array}{c}1.1 \\
\pm 0.14 \\
\mathrm{C}\end{array}$ & $\begin{array}{c}2.43 \\
\pm 0.22 \\
\mathrm{~A}\end{array}$ & $\begin{array}{c}0.625 \\
\pm 0.03 \\
\text { A }\end{array}$ \\
\hline $\begin{array}{c}\text { Site } 3 \\
\text { Eastern sector } \\
\text { (Industrial and } \\
\text { agricultural } \\
\text { effluents) }\end{array}$ & $\begin{array}{c}6.85 \\
\pm 0.23 \\
\text { B }\end{array}$ & $\begin{array}{c}7.3 \\
\pm 0.08 \\
\text { B }\end{array}$ & $\begin{array}{c}335 \\
\pm 2.34 \\
\quad \mathrm{~B}\end{array}$ & $\begin{array}{c}215 \\
\pm 4.23 \\
\text { B }\end{array}$ & $\begin{array}{c}2.8 \\
\pm 0.13 \\
\text { B }\end{array}$ & $\begin{array}{c}1.43 \\
\pm 0.12 \\
\text { B }\end{array}$ & $\begin{array}{c}0.60 \\
\pm 0.03 \\
\text { A }\end{array}$ \\
\hline F- values & $22 * *$ & $6^{*}$ & $46^{* *}$ & $15^{* *}$ & $138 * *$ & $68 * *$ & $61^{* *}$ \\
\hline
\end{tabular}

Data are represented as means of eight samples \pm SE.

Means with the same letters for each parameter are not significantly different, otherwise they do (SAS, 2000).

*Significant difference at $\mathrm{P}<0.05$

**Highly significant difference at $\mathrm{P}<0.01$.

It is clear that, analysis of variance showed highly significant differences ( $\mathrm{P}<0.01)$ for oxygen content values, $\mathrm{pH}$, total hardness, total alkalinity, salinity, ammonia and nitrite among the different studied sites.

It is evident also that, the highest value of dissolved oxygen content was recorded at El-Boughaz inlet (site I) followed by eastern sector (site III) and western sector (site II). This is may be due to the industrial and agricultural discharge high levels of organic substances, inorganic salts and heavy metals lead to hypoxia which cause heavy fish mortality (El-Naggar et al., 1998; Haggag et al., 1999 and Salah El-Deen et al., 1999). The present data also showed high values of water ammonia and nitrite in water samples collected from western and eastern sectors of the lake while the lowest values were recorded at El-Boughaz opening. However, higher water salinity recorded at ElBoughaz opening where water inlet of the Mediterranean sea to the lake.

The total amount of effluents discharged from various urban activities must not be neglected. Heavy metal pollution in water is generally associated 
with industrial, agricultural and municipal discharges (Shenouda et al., 1992; ElNaggar et al., 1998; Nagdi and Shaker, 1998; Salah El-Deen et al., 1999; Zaghloul et al., 2000 and Zaghloul et al., 2005). Once metals are in the water column, they may be taken up by living organisms, deposited in the sediments or remain for some period in the water itself (Salah El-Deen et al., 1999).

Heavy metals are widely distributed in aquatic system due to industrial development and the wide use of chemicals in agriculture. They may lead to either an increase or decrease in growth of various fishes according to their permissible level which are essential for food efficiency and growth rate (Glubokov, 1990). However, higher concentration of heavy metals beyond the tolerance limit of fishes affect fish populations, reducing their growth, reproduction and/or survival and may even kill fishes (Zaghloul et al., 2000 \&2005 and Elghobashy et al ., 2001).

Comparing the average concentrations of heavy metals $\left(\mathrm{Cu}^{++}, \mathrm{Pb}^{++}, \mathrm{Zn}^{++}\right.$ and $\mathrm{Mn}^{++}$) in water from the different locations (Table, 2), the results revealed the presence of metals as follows: Lead $\left(\mathrm{Pb}^{++}\right)$, Eastern sector of the lake $>$ Western sector of the lake > El- Boughaz inlet; Copper $\left(\mathrm{Cu}^{++}\right)$: Western sector of the lake $>$ El-Boughaz inlet $>$ Eastern sector of the lake; Zinc $\left(\mathrm{Zn}^{++}\right)$: Western sector of the lake $>$ Eastern sector of the lake > El-Boughaz inlet; Manganese $\left(\mathrm{Mn}^{++}\right)$: Western sector of the lake $>$Eastern sector of the lake $>$ElBoughaz inlet.

Table ( 2 ): Heavy metal concentrations(mg/l) in water samples collected from different studied sites along lake Burullus.

\begin{tabular}{|c|c|c|c|c|}
\hline Studied sites & Lead & copper & Zinc & Manganese \\
\hline $\begin{array}{l}\text { Site } 1 \\
\quad \text { El-Boughaz inlet }\end{array}$ & $\begin{array}{c}0.049 \\
\pm 0.013 \\
\text { A }\end{array}$ & $\begin{array}{c}0.14 \\
\pm 0.02 \\
\text { B }\end{array}$ & $\begin{array}{c}0.042 \\
\pm 0.009 \\
\quad C\end{array}$ & $\begin{array}{l}0.048 \\
\pm 0.01 \\
\mathrm{C}\end{array}$ \\
\hline $\begin{array}{l}\text { Site } 2 \\
\text { Western sector } \\
\text { (Agricultural effluents) }\end{array}$ & $\begin{array}{l}0.061 \\
\pm 0.01 \\
\quad \mathrm{~A}\end{array}$ & $\begin{array}{c}0.378 \\
\pm 0.027 \\
\quad \text { A }\end{array}$ & $\begin{array}{c}0.340 \\
\pm 0.02 \\
\text { A }\end{array}$ & $\begin{array}{c}0.155 \\
\pm 0.01 \\
\mathrm{~A}\end{array}$ \\
\hline $\begin{array}{l}\text { Site } 3 \\
\text { Eastern sector } \\
\text { (Industrial and } \\
\text { agricultural effluents) }\end{array}$ & $\begin{array}{c}0.078 \\
\pm 0.014 \\
\quad \text { A }\end{array}$ & $\begin{array}{c}0.129 \\
\pm 0.02 \\
\mathrm{~B}\end{array}$ & $\begin{array}{l}0.253 \\
\pm 0.01 \\
\text { B }\end{array}$ & $\begin{array}{l}0.105 \\
\pm 0.01 \\
\quad \mathrm{~B}\end{array}$ \\
\hline F- values & 1.3 & $31^{* *}$ & $103 * *$ & $69 * *$ \\
\hline
\end{tabular}

Data are represented as means of eight samples \pm SE.

Means with the same letter for each parameter are not significantly different, otherwise they do(SAS, 2000).

**Highly significant difference at $\mathrm{P}<0.01$. 
The results declared that in presence of the industrial and agricultural effluents discharged directly to the eastern site of the lake (Site III) and the agricultural effluents discharged directly to the western site of the lake led to the concentrations of copper, zinc and manganese in water were higher than that of samples collected from El-Boughaz inlet (Site I).

However, lead concentrations recorded in water collected from the eastern site is higher than western sector (Table, 2). This may be attributed to gasolin motors all over the lake as previously reported by Shenouda et al.(1992). The high copper, zinc and manganese concentrations in water collected from the eastern and western sectors of the lake could be attributed to the quality of the industrial and agricultural drainage water, which is rich in fertilizers and chemicals, that feeds the lake as shown by Nagdi and Shaker (1998) and Gad (2005).

\section{Residual heavy metals}

Heavy metals are taken up through different organs of the fish according to the affinity between these organs. So, many of these heavy metals are concentrated at different levels in different organs of the fish body (Sorensen, 1991; Salah El-Deen et al., 1999; Elghobashy et al., 2001 and Gad, 2005). Generally, the concentrations of the studied heavy metals $(\mathrm{Cu}, \mathrm{Pb}, \mathrm{Zn}$ and $\mathrm{Mn}$ ) in some selected vital organs (gills, liver, kidney and muscle) of the Nile tilapia; Oreochromis niloticus collected from the different studied sites along El-Burullus lake are significantly higher in the eastern and western sites of the lake (Tables 3, 4, 5 and 6). This may be due to the large amount of agricultural and industrial effluents discharged directly to the lake.

It is clear from the present results that the highest concentrations of the different heavy metals were found in fish collected from the western and eastern sectors of the lake in the following order: liver tissues $>$ kidneys $>$ gills $>$ muscles in case of copper bioaccumulation (Table 3); Gills >liver > kidney and muscles in case of lead bioaccumulation (Table 4). However, zinc and manganese bioaccumulated in fish kidneys at higher concentrations than that in liver (Tables 5 and 6). The results also declared that the lowest concentrations of the studied heavy metals were recorded in tissues of fish collected from ElBoughaz inlet that fed with Mediterranean sea water. 
Table (3): Copper concentrations (mg/kg dry weight) in some vital organs of the Nile tilapia; Oreochromis niloticus collected from different studied sites along lake Burullus.

\begin{tabular}{|c|c|c|c|c|}
\hline Organs & Gills & Liver & kidney & $\begin{array}{l}\text { Muscles } \\
(\mathrm{P} . \mathrm{L}=20 \mathrm{ppm})\end{array}$ \\
\hline $\begin{array}{c}\text { Site } 1 \\
\text { El-Boughaz inlet }\end{array}$ & $\begin{array}{c}0.90 \\
\pm 0.08 \\
\quad \mathrm{~B}\end{array}$ & $\begin{array}{l}10.15 \\
\pm 0.39 \\
\quad \mathrm{C}\end{array}$ & $\begin{array}{l}6.55 \\
\pm 0.24 \\
\text { B }\end{array}$ & $\begin{array}{c}0.36 \\
\pm 0.02 \\
\text { B }\end{array}$ \\
\hline $\begin{array}{c}\text { Site } 2 \\
\text { Western sector } \\
\text { (Agricultural effluents) }\end{array}$ & $\begin{array}{c}1.65 \\
\pm 0.21 \\
\mathrm{~A}\end{array}$ & $\begin{array}{c}15.1 \\
\pm 0.6 \\
\mathrm{~A}\end{array}$ & $\begin{array}{l}8.9 \\
\pm 0.53 \\
\mathrm{~A}\end{array}$ & $\begin{array}{l}0.72 \\
\pm 0.08 \\
\mathrm{~A}\end{array}$ \\
\hline $\begin{array}{c}\text { Site } 3 \\
\text { Eastern sector } \\
\text { (Industrial and agricultural } \\
\text { effluents) }\end{array}$ & $\begin{array}{c}1.3 \\
\pm 0.15 \\
\text { A/B }\end{array}$ & $\begin{array}{l}12.95 \\
\pm 0.59 \\
\text { B }\end{array}$ & $\begin{array}{c}8.1 \\
\pm 0.53 \\
\mathrm{~A}\end{array}$ & $\begin{array}{c}0.7 \\
\pm 0.04 \\
\quad \text { A }\end{array}$ \\
\hline F- values & $5.9^{* *}$ & $21^{* *}$ & $6.9^{* *}$ & $14.6^{* *}$ \\
\hline
\end{tabular}

Data are represented as means of eight samples \pm SE.

P. L = Permissible level, (WHO, 1989).

Means with the same letter for each parameter in the same column are not significantly different, otherwise they do (SAS, 2000).

**Highly significant difference at $\mathrm{P}<0.01$.

Table (4): Lead concentrations (mg/kg dry weight) in some vital organs of the Nile tilapia; Oreochromis niloticus, collected from different studied sites lake Burullus.

\begin{tabular}{|c|c|c|c|c|}
\hline $\begin{array}{c}\text { Organs } \\
\text { Studied sites } \\
\end{array}$ & Gills & Liver & kidney & $\begin{array}{c}\text { Muscles } \\
\text { P.L }=0.6 \mathrm{ppm}\end{array}$ \\
\hline $\begin{array}{c}\text { Site } 1 \\
\text { El-Boughaz inlet }\end{array}$ & $\begin{array}{c}1.3 \\
\pm 0.12 \\
\mathrm{~B}\end{array}$ & $\begin{array}{c}1.28 \\
\pm 0.09 \\
\mathrm{C}\end{array}$ & $\begin{array}{c}0.55 \\
\pm 0.04 \\
\text { B }\end{array}$ & $\begin{array}{c}0.15 \\
\pm 0.01 \\
\mathrm{C}\end{array}$ \\
\hline $\begin{array}{c}\text { Site } 2 \\
\text { Western sector } \\
\text { (Agricultural effluents) }\end{array}$ & $\begin{array}{c}3.28 \\
\pm 0.19 \\
\text { A }\end{array}$ & $\begin{array}{c}2.98 \\
\pm 0.12 \\
\text { A }\end{array}$ & $\begin{array}{c}1.8 \\
\pm 0.09 \\
\text { A }\end{array}$ & $\begin{array}{c}0.45 \\
\pm 0.02 \\
\text { A }\end{array}$ \\
\hline $\begin{array}{c}\text { Site } 3 \\
\text { Eastern sector } \\
\text { (Industrial and agricultural } \\
\text { effluents) }\end{array}$ & $\begin{array}{c}3.45 \\
\pm 0.15 \\
\text { A }\end{array}$ & $\begin{array}{c}2.35 \\
\pm 0.16 \\
\text { B }\end{array}$ & $\begin{array}{c}1.61 \\
\pm 0.07 \\
\text { A }\end{array}$ & $\begin{array}{c}0.297 \\
\pm 0.02 \\
\text { B }\end{array}$ \\
\hline F-values & $60 * *$ & $47 * *$ & $85^{* *}$ & $56^{* *}$ \\
\hline
\end{tabular}

Data are represented as means of eight samples \pm SE.

P. L = Permissible level. (WHO, 1989).

Means with the same letter for each parameter are not significantly different, otherwise they do(SAS, 2000).

**Highly significant difference at $\mathrm{P}<0.01$. 
Table (5) : Zinc concentrations (mg/kg dry weight) in some vital organs of the Nile tilapia; Oreochromis niloticus, collected from different studied sites along lake Burullus.

\begin{tabular}{|c|c|c|c|c|}
\hline Organs & Gills & Liver & kidney & $\begin{array}{c}\text { Muscles } \\
\text { P.L= } 50 \text { ppm }\end{array}$ \\
\hline $\begin{array}{c}\text { Site } 1 \\
\text { El-Boughaz inlet }\end{array}$ & $\begin{array}{c}14.5 \\
\pm 1.02 \\
\mathrm{C}\end{array}$ & $\begin{array}{c}24.5 \\
\pm 1.149 \\
\quad \text { C }\end{array}$ & $\begin{array}{c}61.0 \\
\pm 2.19 \\
\mathrm{~B}\end{array}$ & $\begin{array}{c}22.3 \\
\pm 1.42 \\
\mathrm{C}\end{array}$ \\
\hline $\begin{array}{c}\text { Site } 2 \\
\text { Western sector } \\
\text { (Agricultural effluents) }\end{array}$ & $\begin{array}{c}38.75 \\
\pm 1.93 \\
\text { A }\end{array}$ & $\begin{array}{c}51.5 \\
\pm 2.59 \\
\text { A }\end{array}$ & $\begin{array}{c}118.0 \\
\pm 5.99 \\
\text { A }\end{array}$ & $\begin{array}{c}31.0 \\
\pm 0.89 \\
\text { A }\end{array}$ \\
\hline $\begin{array}{c}\text { Site } 3 \\
\text { Eastern sector } \\
\text { (Industrial and agricultural } \\
\text { effluents) }\end{array}$ & $\begin{array}{c}29.0 \\
\pm 1.16 \\
\mathrm{~B}\end{array}$ & $\begin{array}{c}39.0 \\
\pm 0.71 \\
\text { B }\end{array}$ & $\begin{array}{c}113 \\
\pm 7.99 \\
\mathrm{~A}\end{array}$ & $\begin{array}{c}26.5 \\
\pm 0.68 \\
\text { B }\end{array}$ \\
\hline F-values & $73^{* *}$ & $64 * *$ & $28 * *$ & $18^{* *}$ \\
\hline
\end{tabular}

Data are represented as means of eight samples \pm SE.

P.L = Permissible level (WHO, 1989).

Means with the same letter for each parameter are not significantly different , otherwise they do (SAS, 2000). $\quad * *$ Highly significant difference at $\mathrm{P}<0.01$.

Table (6): Manganse concentrations (mg/kg dry weight) in some vital organs of the Nile tilapia; Oreochromis niloticus, collected from different studied sites along lake Burullus.

\begin{tabular}{|c|c|c|c|c|}
\hline $\begin{array}{c}\text { Qrgans } \\
\text { Studied sites } \\
\end{array}$ & Gills & Liver & kidney & $\begin{array}{c}\text { Muscles } \\
\text { P. L. }=6.5 \text { ppm }\end{array}$ \\
\hline $\begin{array}{c}\text { Site 1 } \\
\text { El-Boughaz inlet }\end{array}$ & $\begin{array}{c}0.95 \\
\pm 0.08 \\
\mathrm{C}\end{array}$ & $\begin{array}{c}10.5 \\
\pm 0.87 \\
\text { B }\end{array}$ & $\begin{array}{c}16.0 \\
\pm 0.96 \\
\text { B }\end{array}$ & $\begin{array}{c}1.08 \\
\pm 0.10 \\
\mathrm{C}\end{array}$ \\
\hline $\begin{array}{c}\text { Site } 2 \\
\text { Western sector } \\
\text { (Agricultural effluents) } \\
\end{array}$ & $\begin{array}{c}1.93 \\
\pm 0.13 \\
\text { A }\end{array}$ & $\begin{array}{l}18.75 \\
\pm 0.56 \\
\text { A }\end{array}$ & $\begin{array}{c}51.75 \\
\pm 3.37 \\
\text { A }\end{array}$ & $\begin{array}{c}2.93 \\
\pm 0.11 \\
\text { A }\end{array}$ \\
\hline $\begin{array}{c}\text { Site } 3 \\
\text { Eastern sector } \\
\text { (Industrial and agricultural effluents) } \\
\end{array}$ & $\begin{array}{c}1.44 \\
\pm 0.05 \\
\text { B }\end{array}$ & $\begin{array}{c}17.0 \\
\pm 0.46 \\
\text { A }\end{array}$ & $\begin{array}{c}46.5 \\
\pm 2.34 \\
\text { A }\end{array}$ & $\begin{array}{c}2.23 \\
\pm 0.09 \\
\mathrm{~B}\end{array}$ \\
\hline F- values & $29 * *$ & $44^{* *}$ & $63^{* *}$ & $87^{* *}$ \\
\hline
\end{tabular}

Data are represented as means of eight samples \pm SE.

P. L = Permissible level, (WHO, 1989).

Means with the same letter for each parameter are not significantly different, otherwise they do

(SAS, 2000). $\quad * *$ Highly significant difference at $\mathrm{P}<0.01$. 
Heavy metals accumulate mainly in metabolic organs such as liver that stores metals to detoxicate by producing metallothioneins (Sorensen, 1991). In general, heavy metal levels were higher in the gill than the muscle tissue of fish. Metal concentration in the gill could be due to the element complexion with the mucus that is impossible to completely remove from the lamellae, before tissue is prepared for analysis. The adsorption of metals onto the gill surface, as the first target for pollutants in water, could also be an important influence in the total metal levels of the gill (Heath, 1995).

\section{Condition factor:}

The values of the condition factor " $k$ " are estimated for comparative purposes to assess the impact of environmental alterations on fish performance (Clark and Fraser, 1983). Therefore, the fluctuation in "k" may reflect the health condition of the fish as well as their protein and lipid contents (Weatherley and Gill, 1983).

In the present study, the condition factor of Oreochromis niloticus, collected from the different studied sites along the lake fluctuated to be the highest in fish collected from El-Boughaz inlet and the lowest in fish collected from the eastern and western sectors of the lake (Table 7). The obtained data are in agreement with Fletcher and White (1976) and White and Fletcher (1985) who found fluctuation in $\mathrm{k}$ values of fish and attributed these changes in $\mathrm{k}$ factors to the feeding rate and to lipid mobilization.

Table (7): Condition factor (k), hepatosomatic index (HSI) and liver water content of the Nile tilapia;Oreochromis niloticus, collected from different studied sites along lake Burullus.

\begin{tabular}{|c|c|c|c|}
\hline Parameters & $\begin{array}{c}\text { Condition factor } \\
\text { (K) }\end{array}$ & $\begin{array}{l}\text { Hepatosomatic index } \\
\text { (HSI) }\end{array}$ & $\begin{array}{l}\text { Liver water } \\
\text { content } \\
(\%)\end{array}$ \\
\hline $\begin{array}{c}\text { Site 1 } \\
\text { ( El-Boughaz inlet) }\end{array}$ & $\begin{array}{c}1.66 \\
\pm 0.01 \\
\mathrm{~A} \\
\end{array}$ & $\begin{array}{c}1.11 \\
\pm 0.07 \\
\mathrm{~A} \\
\end{array}$ & $\begin{array}{c}78.28 \\
\pm 0.41 \\
\mathrm{~B} \\
\end{array}$ \\
\hline $\begin{array}{c}\text { Site } 2 \\
\text { (western sector) } \\
\text { (Agricultural effluents) }\end{array}$ & $\begin{array}{c}1.45 \\
\pm 0.02 \\
\mathrm{~B}\end{array}$ & $\begin{array}{c}0.61 \\
\pm 0.12 \\
\mathrm{~B}\end{array}$ & $\begin{array}{c}79.9 \\
\pm 0.28 \\
\text { A }\end{array}$ \\
\hline $\begin{array}{c}\text { Site } 3 \\
\text { ( eastern sector) } \\
\text { (Industrial and } \\
\text { agricultural effluents) }\end{array}$ & $\begin{array}{c}1.48 \\
\pm 0.03 \\
\text { B }\end{array}$ & $\begin{array}{c}0.78 \\
\pm 0.07 \\
\text { B }\end{array}$ & $\begin{array}{c}79.6 \\
\pm 0.36 \\
\text { A }\end{array}$ \\
\hline F- values & $29 * *$ & $8 * *$ & $6^{*}$ \\
\hline
\end{tabular}

Data are represented as means of eight samples \pm SE.

Means with the same letter for each parameter are not significantly different, otherwise they do (SAS, 2000).

* Significant difference at $\mathrm{P}<0.05 \quad * *$ Highly significant difference at $\mathrm{P}<0.01$. 
The lower values of the condition factor " $\mathrm{k}$ " of Oreochromis niloticus, collected from the eastern and western sectors of the lake may be due to the toxic effect of the different heavy metals accumulated at high concentrations in the various tissues of the fish (Clark and Fraser, 1983; Haggag, et al., 1999 and Salah El-Deen et al.,1999) and/or the low densities of both phyto and zooplankton that may accompanied the deterioration of water quality as previously reported by Shaaban et al. (1999). On the other hand, the high $\mathrm{k}$ values of collected fish from El- Boughaz inlet is in agreement with the finding obtained by Kheir et al. (1998b) who attributed these results to the osmoregulatory factor, increase of food consumption as a result of increased metabolism, minimized oxygen consumption and an increase in growth hormones.

The present study indicates that the hepatosomatic index which is another biological parameter that helps in studying growth of fish (Weatherley and Gill, 1987). This index did not change significantly $(\mathrm{P}>0.05)$ between fish collected from the eastern and western sites. Otherwise, there is a significant decrease $(\mathrm{P}<0.01)$ in hepatosomatic index of collected fish from the eastern and western sites in relation to that collected from El-Boughaz inlet. Such results are in agreement with those of Haggag et al. (1999) and Salah El-Deen et al. (1999) who attributed that to a depletion of liver glycogen followed by hyperglycemia that reflects the fish's need for energy necessary to resist the stress. This is confirmed by hyperglycemia in fish collected from eastern and western sector of the lake.

The liver water content showed that there was only slight dehydration in fish collected from the brackish water El- Boughaz inlet (Table 7). This finding is in harmony with that recorded by Woo et al.(1997) and Kheir et al.(1998a) who attributed that to osmoregulation.

\section{Blood parameters}

Haematological components have been developed for evaluation of fish health conditions (Aldrin et al., 1982). As a matter of fact, blood serves as the most convenient indicator of the general condition of the animal body. Subsequently, haematological studies are promising tools for investigating physiological changes caused by environmental pollutants (Haggag et al., 1999; Zaghloul, 2001 and Zaghloul et al., 2005).

Data representing in Table (8) showed the blood parameters of Oreochromis niloticus collected from the different studied sites along ElBurullus lake.

Comparison of the red blood cell counts of Oreochromis niloticus (Table 8), the present results revealed that there is highly significant difference $(\mathrm{P}<0.01)$ in RBCs count of fish collected from the different studied sites of the lake. Moreover, fish collected from the western $\left\{(0.63 \pm 0.02) \times 10^{6} / \mathrm{mm}^{3}\right\}$ and the eastern $\left\{(0.83 \pm 0.03) \times 10^{6} / \mathrm{mm}^{3}\right\}$ sites of the lake had a significant decrease (P 
$<0.01)$ in RBCs count, than that of fish collected from El- Boughaz inlet $\left\{(1.25 \pm 0.04) \times 10^{6} / \mathrm{mm}^{3}\right\}$.

Moreover, fish collected from the western site of the lake showed a significant decrease $(\mathrm{P}<0.01)$ in haemoglobin content followed by that of fish collected from the eastern site. In the same trend fish collected from the eastern and western sites of the lake showed a significant decrease $(\mathrm{P}<0.01)$ in haematocrit value (Table 8).

Table (8): Blood parameters of the Nile tilapia; Oreochromis niloticus, collected from different studied sites along lake Burullus.

\begin{tabular}{|c|c|c|c|c|c|c|c|}
\hline Blood & $\begin{array}{l}\text { RBCs } \\
\left(\mathrm{X} 10^{6}\right. \\
\left./ \mathrm{mm}^{3}\right)\end{array}$ & $\begin{array}{c}\mathrm{Hb} \\
\text { (g/100ml) }\end{array}$ & $\begin{array}{l}\mathrm{Ht} \\
(\%)\end{array}$ & $\begin{array}{l}\text { MCV } \\
\left(\mu m^{3}\right. \\
/ \text { cell })\end{array}$ & $\begin{array}{r}\mathrm{MCH} \\
\text { (pg/cell) }\end{array}$ & $\begin{array}{c}\text { MCHC } \\
(\mathrm{g} / 100 \mathrm{ml})\end{array}$ & $\begin{array}{l}\text { WBCs } \\
\left(\mathrm{X} 10^{3}\right. \\
\left./ \mathrm{mm}^{3}\right)\end{array}$ \\
\hline $\begin{array}{c}\text { Site } 1 \\
\text { (El-Boughaz } \\
\text { inlet) }\end{array}$ & $\begin{array}{c}1.25 \\
\pm 0.04 \\
\mathrm{~A}\end{array}$ & $\begin{array}{c}6.03 \\
\pm 0.17 \\
\mathrm{~A}\end{array}$ & $\begin{array}{c}16 \\
\pm 0.71 \\
\mathrm{~A}\end{array}$ & $\begin{array}{c}128 \\
\pm 1.8 \\
\text { B }\end{array}$ & $\begin{array}{c}48.3 \\
\pm 0.34 \\
\text { C }\end{array}$ & $\begin{array}{c}37.9 \\
\pm 0.69 \\
\text { A }\end{array}$ & $\begin{array}{c}22.3 \\
\pm 0.31 \\
\text { C }\end{array}$ \\
\hline $\begin{array}{c}\text { Site } 2 \\
\text { ( western } \\
\text { sector) } \\
\text { (Agricultural } \\
\text { effluents) }\end{array}$ & $\begin{array}{c}0.63 \\
\pm 0.02 \\
\text { C }\end{array}$ & $\begin{array}{c}3.38 \\
\pm 0.21 \\
\mathrm{C}\end{array}$ & $\begin{array}{c}10.25 \\
\pm 0.49 \\
\text { C }\end{array}$ & $\begin{array}{c}159 \\
\pm 3.9 \\
\text { A }\end{array}$ & $\begin{array}{c}52.2 \\
\pm 1.8 \\
\text { B }\end{array}$ & $\begin{array}{c}32.8 \\
\pm 0.54 \\
\text { B }\end{array}$ & $\begin{array}{c}31.5 \\
\pm 1.38 \\
\text { A }\end{array}$ \\
\hline $\begin{array}{c}\text { Site } 3 \\
\text { (eastern } \\
\text { sector) } \\
\text { (Industrial } \\
\text { and } \\
\text { agricultural } \\
\text { effluents) }\end{array}$ & $\begin{array}{c}0.83 \\
\pm 0.03 \\
\text { B }\end{array}$ & $\begin{array}{c}4.95 \\
\pm 0.15 \\
\text { B }\end{array}$ & $\begin{array}{c}13.1 \\
\pm 0.51 \\
\text { B }\end{array}$ & $\begin{array}{c}161 \\
\pm 2.6 \\
\text { A }\end{array}$ & $\begin{array}{c}60.8 \\
\pm 0.82 \\
\text { A }\end{array}$ & $\begin{array}{c}37.8 \\
\pm 0.48 \\
\text { A }\end{array}$ & $\begin{array}{c}27.75 \\
\pm 0.62 \\
\text { B }\end{array}$ \\
\hline F- values & $101^{* *}$ & $56 * *$ & $25^{* *}$ & $41^{* *}$ & $30 * *$ & $26 * *$ & $27 * *$ \\
\hline
\end{tabular}

Data are represented as means of eight samples \pm SE.

Means with the same letter for each parameter are not significantly different, otherwise they do (SAS, 2000).

**Highly significant difference at $\mathrm{P}<0.01$.

It can be refer these results to some factors as heavy metal exposure that is known to induce changes in blood parameters of the fish (Heath, 1995). The highly significant $(\mathrm{P}<0.01)$ decrease in RBCs, $\mathrm{Hb}$ and $\mathrm{Ht}$ values of collected 
fish from the eastern and western sectors of the lake may be due to reduction in red blood corpuscles production in the haematopoietic organs under the action of high heavy metal concentrations recorded in water samples (Table 2). These results are supported by Marie (1990) and Zaghloul et al. (2005). Such a reduction may be also due to the intrahepatic and intrasplenic haemorrage induced by the action of accumulated heavy metals in the present study (photomicrograph 2).

Comparison of the white blood cell counts of Oreochromis niloticus, declared that, there was highly significant $(\mathrm{P}<0.01)$ difference in WBCs of fish collected from the different studied sites along lake Burullus. Moreover, fish collected from the western and eastern sites of the lake had a significant increase in WBCs count, than that of fish collected from El-Boughaz opening.

Leukocytosis reported in the present study may be attributed to increased leukocyte mobilization to protect the body against infections in metals-damaged tissue. This is in agreement with the finding of Nussey et al., (1995 a, b) in O. mossambicus and Mazon et al. (2002) in Prochilodus scrofa after acute exposure to copper. The increase in WBCs of fish was suggested to indicate alteration in defense mechanism against the action of the highly toxic and the bioaccumulated heavy metals in fish tissues as previously reported by Haggag et al. (1999); Zaghloul (2001); Mazon et al.,(2002) and Zaghloul et al. (2005).

Regarding the mean corpuscular volume (MCV), mean corpuscular haemoglobin (MCH) and mean corpuscular haemoglobin concentration (MCHC) of Oreochromis niloticus collected from the different studied sites, there were highly significant $(\mathrm{P}<0.01)$ difference in $\mathrm{MCV}, \mathrm{MCH}$ and $\mathrm{MCHC}$ of fish from the different studied sites along El-Burullus lake. Moreover, fish collected from the western and eastern sector of the lake had significant $(\mathrm{P}<0.05)$ increase in $\mathrm{MCV}$ and MCH (Table 8).

The changes in red blood cell parameters suggest a compensatory response to the disruption of structural integrity of gills with consequent reduction of respiratory surface(tissue damage and cell proliferation), in order to increase $\mathrm{O}_{2}$-carrying capacity and maintain the level of oxygen transference from water to tissues (Zaghloul et al., 2005). The same histopathological alterations were recorded in the present study, where clear damage in gills of fish collected from eastern and western sector of the lake (Photomicrograph, 1).

The decrease in blood $\mathrm{Hb}$ content is accompanied by an increase in mean corpuscular volume (MCV) and mean corpuscular haemoglobin (MCH). This may be due to the haemolytic action that led to fluid loss to the tissues with subsequent decrease in plasma volume (Swift, 1981). 


\section{Serum constituents}

The serum constituents have proved to be useful in the detection and diagnosis of metabolic disturbance and disease (Aldrin et al., 1982).

The present study showed highly significant differences $(\mathrm{P}<0.01)$ in the studied serum constituents where the highest values in serum glucose, AST, ALT, creatinine and uric acid and lowest values in serum total lipids of the studied fish (Table 9).

Table (9): Serum constituents of the Nile tilapia; Oreochromis niloticus, collected from different studied sites along lake Burullus.

\begin{tabular}{|c|c|c|c|c|c|c|c|}
\hline $\begin{array}{l}\text { Serump } \\
\text { constituents } \\
\text { Studied sites }\end{array}$ & $\begin{array}{r}\text { Glucose } \\
(\mathrm{mg} / 100 \mathrm{ml})\end{array}$ & $\begin{array}{r}\text { Total } \\
\text { protein } \\
(\mathrm{g} / 100 \mathrm{ml})\end{array}$ & $\begin{array}{l}\text { Total } \\
\text { lipids } \\
(\mathrm{g} / \mathrm{l})\end{array}$ & $\begin{array}{l}\text { AST } \\
(\mathrm{u} / \mathrm{l})\end{array}$ & $\begin{array}{l}\text { ALT } \\
(\mathrm{u} / \mathrm{l})\end{array}$ & $\begin{array}{l}\text { Creatinine } \\
(\mathrm{mg} / 100 \mathrm{ml})\end{array}$ & $\begin{array}{r}\text { Uric acid } \\
(\mathrm{mg} / 100 \mathrm{ml})\end{array}$ \\
\hline $\begin{array}{l}\text { Site } 1 \\
\text { ( El-Boughaz } \\
\text { inlet) }\end{array}$ & $\begin{array}{c}58 \\
\pm 2.24 \\
\quad \mathrm{C}\end{array}$ & $\begin{array}{c}4.08 \\
\pm 0.1 \\
\mathrm{~A}\end{array}$ & $\begin{array}{c}5.2 \\
\pm 0.19 \\
\quad \text { A }\end{array}$ & $\begin{array}{c}11.75 \\
\pm 0.31 \\
\quad \mathrm{C}\end{array}$ & $\begin{array}{c}6.45 \\
\pm 0.16 \\
\mathrm{C}\end{array}$ & $\begin{array}{c}2.07 \\
\pm 0.1 \\
\mathrm{C}\end{array}$ & $\begin{array}{c}7.45 \\
\pm 0.19 \\
\mathrm{C}\end{array}$ \\
\hline \begin{tabular}{l} 
Site 2 \\
( western \\
\multicolumn{1}{c}{ sector) } \\
(Agricultural \\
effluents)
\end{tabular} & $\begin{array}{c}118.5 \\
\pm 6.2 \\
\mathrm{~A}\end{array}$ & $\begin{array}{c}1.98 \\
\pm 0.11 \\
\mathrm{C}\end{array}$ & $\begin{array}{c}2.9 \\
\pm 0.17 \\
\quad \mathrm{C}\end{array}$ & $\begin{array}{c}25.8 \\
\pm 0.98 \\
\text { A }\end{array}$ & $\begin{array}{c}15.3 \\
\pm 0.55 \\
\text { A }\end{array}$ & $\begin{array}{c}6.08 \\
\pm 0.29 \\
\text { A }\end{array}$ & $\begin{array}{c}26.5 \\
\pm 0.68 \\
\text { A }\end{array}$ \\
\hline $\begin{array}{c}\text { Site } 3 \\
\text { (Eastern } \\
\text { sector) } \\
\text { (Industrial and } \\
\text { agricultural } \\
\text { effluents) } \\
\end{array}$ & $\begin{array}{c}87.3 \\
\pm 2.2 \\
\text { B }\end{array}$ & $\begin{array}{c}2.33 \\
\pm 0.06 \\
\text { B }\end{array}$ & $\begin{array}{c}3.93 \\
\pm 0.11 \\
\text { B }\end{array}$ & $\begin{array}{c}21.0 \\
\pm 0.61 \\
\text { B }\end{array}$ & $\begin{array}{c}13.25 \\
\pm 0.56 \\
\text { B }\end{array}$ & $\begin{array}{c}5.075 \\
\pm 0.21 \\
\text { B }\end{array}$ & $\begin{array}{c}22.25 \\
\pm 0.98 \\
\text { B }\end{array}$ \\
\hline F- values & $53 * *$ & $135^{* *}$ & $37 * *$ & $101^{* *}$ & $85 * *$ & $89 * *$ & $162 * *$ \\
\hline
\end{tabular}

Data are represented as means of eight samples \pm SE.

Means with the same letter for each parameter are not significantly different, otherwise they do(SAS, 2000).

**Highly significant difference at $\mathrm{P}<0.01$.

The reported hyperglycemia in the present study may be due to an enhanced glycogen breakdown in liver, that may affected by the bioaccumulation of the studied heavy metals and/or an increase in plasma concentration of catecholamines and corticosteroids as a stress response of fish subjected to environmental alteration (Mazeaud et al., 1977) or glycogen depletion in fish submitted to various stress conditions (Hinton et al., 1978 and Paris-Palacios et al.,2000). 
Serum total proteins play an important role in the metabolism and regulation of water balance (Heath, 1995). Blood protein and enzyme levels, in rainbow trout, are affected by metals (Dethloff et al., 1999). The pesticide, cypermethrin, has been shown to cause a decrease in both structural and soluble proteins in common carp, Cyprinus carpio (Malla Reddy and Bashamohideen, 1995).

In the present study, serum total protein concentrations of fish collected from El- Boughaz inlet are within the normal range as reported by Ghazaly and Said (1995) and Zaghloul et al. (2005). However, exposure of the studied fish to the effluents at the eastern and western sites of the lake decreased the serum total protein to lower levels than those of the fish collected from El-Boughaz inlet. The recorded hypoproteinamiais may be explained on the basis of energy production during pollutant toxicity and/or due to other several pathological processes including renal damage and elimination in hepatic blood flow and/or plasma dissolution as reported by Gluth and Hanke (1985).

Moreover, synthesis of metal binding protein, the metalothionin is induced by the action of many factors such as stress of heavy metals (McCarter and Roch, 1984). The increase in the serum total protein level was reported by Ghazaly and Said (1995) for Oreochromis niloticus exposed to sublethal concentration of copper $(1.14 \mathrm{mg} / \mathrm{l})$ for 96 hrs; El-Naggar et al (1998) for Oreochromis niloticus collected from the polluted area along the river Nile at the industrial zone of Helwan and Zaghloul et al. (2000) in case of the Nile tilapia; Oreochromis niloticus and the Nile catfish; Clarias gariepinus collected from ponds irrigated agricultural drainage water.

Lipids are important metabolite for locomotory and reproductory activities of fish. The significant decrease $(\mathrm{P}<0.05)$ in the serum total lipids of fish collected from the eastern and western sites of the lake may be attributed to the increase in the secretion of catecholamines (Pickering, 1981) and corticosteroids (Mazeaud et al., 1977) as result of pollutant stress which enhanced metabolic rate and in turn reduced metabolic reserve. The obtained results also coincided with those of Caulton (1982) who reported that mobilization of body protein and lipids for catabolic processes has been found to increase with the deterioration of fish condition and habitat.

Determination of enzymatic activities in the fish could be applied to monitor water pollution (Heath, 1995). The elevation in serum AST and ALT activities of fish collected from the eastern and western sites, as compared with that of El- Boughaz inlet may be attributed to the damage of liver (Photomicrograph, 2) and kidney (Photomicrograph, 3) cells by the action of the accumulated heavy metals. The same results were previously reported in case of different fish species exposed to different heavy metals (Zaghloul, et al. 2000; Zaghloul, 2001; Elghobashy et al., 2001 and Gad, 2005)

Indeed following cell damage, the membranes become permeable and the enzymes are found in the extracellular fluid and serum. So, determination of 
transaminases, (AST, ALT) has proven useful in the diagnosis of liver disease in fish (Maita et al., 1984 and Sandnes et al., 1988). Also, Cell injury of certain organs leads to the release of tissue-specific enzymes into the blood stream (Heath 1995 and Burtis and Ashwood 1996). The significant $(P<0.05)$ increased of transaminases (AST and ALT) activity in fish exposed to cheavy metals may reveal possible leakage of enzymes across damaged plasma membranes and/or the increased synthesis of enzymes by the liver.

Serum creatinine and uric acid can be used as a rough index of the glomerular filtration rate (Maita et al., 1984). Low concentrations of creatinine, uric acid and urea have no significant but high values indicate the presence of disturbances in the kidney (Maxine and Benjamine, 1985).

In the present study, fish collected from eastern and western sites of the lake had an elevation in serum creatinine and uric acid. This may be attributed to the action of heavy metals on the glomerular filtration rate, which causes pathological changes of the kidney (Sorensen, 1991; Heath, 1995 and Zaghloul, 2001). Elevated serum creatinine and uric acid levels can be used as indicators of kidney dysfunction (Lockhart and Metnar, 1984). Deficiency of oxygen as well as wastes from the processing industries induced an increase creatinine concentration of fish blood (Oikari and Soivio, 1977). Accumulation of heavy metals in the kidney caused malfunction and damage of the renal cells followed by an increase in serum creatinine and uric acid levels (Ghazally and Said, 1995; El-Naggar et al., 1998; Haggag et al., 1999 and Zaghloul, 2000).

\section{Muscle chemical composition (Meat quality)}

Data representing in Table (10) showed the changes in meat quality of the Nile tilapia; Oreochromis niloticus collected from the different studied sites along lake Burullus.

Regarding the muscle water content (\%) of the Nile tilapia; Oreochromis niloticus collected from the different sites along the lake (Table 10), there is highly significant $(\mathrm{P}<0.01)$ difference among fish collected from the different studied sites. The lowest values of water content of muscle in fish collected from El-Boughaz inlet $(79 \pm 0.27)$ and highest values in fish collected from the eastern $(81.11 \pm 0.14)$ and western $(81.38 \pm 0.7)$ sector.

The metabolic pathways of fish can be severely altered by a variety of biological, chemical and physiological factors, which could be assessed throughout several biochemical procedures. The influence of toxicants on muscle chemical composition of fish has been taken into account in evaluating response of the fish against stressors especially heavy metals (Haggag et al., 1999 and Zaghloul, 2001). 
Table (10): Muscle chemical composition of the Nile tilapia; Oreochromis niloticus, collected from different studied sites along lake Burullus.

\begin{tabular}{|c|c|c|c|c|}
\hline $\begin{array}{l}\text { Muscle chemical } \\
\text { composition } \\
\text { Studied sites }\end{array}$ & $\begin{array}{l}\text { MuscleWater } \\
\text { content } \\
(\%)\end{array}$ & $\begin{array}{l}\text { MuscleTotal } \\
\text { protein } \\
\text { ( \% of wet } \\
\text { weight) }\end{array}$ & $\begin{array}{l}\text { MuscleTotal } \\
\text { lipids } \\
\text { (\% of wet } \\
\text { weight ) }\end{array}$ & $\begin{array}{c}\text { MuscleAsh } \\
(\%)\end{array}$ \\
\hline $\begin{array}{c}\text { Site } 1 \\
\text { ( El-Boughaz inlet) }\end{array}$ & $\begin{array}{l}79 \\
+0.27 \\
\quad \mathrm{~B}\end{array}$ & $\begin{array}{c}16.93 \\
\pm 0.16 \\
\text { A }\end{array}$ & $\begin{array}{c}3.08 \\
\pm 0.10 \\
\text { A }\end{array}$ & $\begin{array}{l}2.33 \\
\pm 0.07 \\
\quad \mathrm{~B}\end{array}$ \\
\hline $\begin{array}{c}\text { Site } 2 \\
\text { ( western sector) } \\
\text { (Agricultural } \\
\text { effluents) }\end{array}$ & $\begin{array}{c}81.38 \\
\pm 0.7 \\
\mathrm{~A}\end{array}$ & $\begin{array}{l}12.23 \\
\pm 0.19 \\
\quad \mathrm{C}\end{array}$ & $\begin{array}{l}2.3 \\
\pm 0.13 \\
\mathrm{C}\end{array}$ & $\begin{array}{l}3.37 \\
\pm 0.2 \\
\mathrm{~A}\end{array}$ \\
\hline $\begin{array}{c}\text { Site } 3 \\
\text { (Eastern sector) } \\
\text { (Industrial and } \\
\text { agricultural effluents) }\end{array}$ & $\begin{array}{l}81.11 \\
\pm 0.14 \\
\quad \mathrm{~A}\end{array}$ & $\begin{array}{c}13.55 \\
\pm 0.2 \\
\mathrm{~B}\end{array}$ & $\begin{array}{l}2.68 \\
\pm 0.11 \\
\text { B }\end{array}$ & $\begin{array}{c}3.25 \\
\pm 0.22 \\
\quad \mathrm{~A}\end{array}$ \\
\hline F- values & $8.7 * *$ & $172 * *$ & $11.3^{* *}$ & $10.4^{* *}$ \\
\hline
\end{tabular}

Data are represented as means of eight samples \pm SE.

Means with the same letter for each parameter are not significantly different, otherwise they do (SAS, 2000).

**Highly significant difference at $\mathrm{P}<0.01$.

In the present study, fish exposed to industrial and agricultural effluents of the lake at eastern and western sector showed the lowest meat quality. Moreover, there were a significant $(\mathrm{P}<0.05)$ increase in muscle water content and ash while a significant decrease $(\mathrm{P}<0.05)$ in the muscle total protein and total lipids. These results are in agreement with Zaghloul (2001) and Elghobashy et al. (2001) who recorded a decrease in the muscle total protein and total lipids of the African catfish; Clarias gariepinus and Nile tilapia; Oreochromis niloticus exposed to high concentrations of heavy metals.

Depletion of body constituents (muscle total protein and total lipids) results in tissue hydration. This explanation is in agreement with Weatherley and Gill (1987) who reported that, there is an inverse dynamic relationship between protein as well as lipids and water contents in the muscles. Moreover, El-Sayed et al. (1996) illustrated that the decrease in body protein and lipids at inappropriate habitat was a direct effect of the utilization of body protein and / or fat as energy supply to meet the increasing physiological demands.

Also, the decrease in muscle total protein and total lipids of fish may be attributed to the highly bioaccumulated metals in gills. The bioaccumulated copper, zinc, manganese and lead leads to damage in the gill structure, a reduction in the rate of oxygen consumption that causes a sharp reduction in 
metabolic rate shown by deceleration in fish growth as previously reported by Reader et al. (1989). In the same trend, the decrease in muscle total protein and total lipids may also be attributed to the decrease in insulin level, detected by the recognized hyperglycemia, which has greater effect on proteogenic and lipogenic pathways (Ablett et al., 1981).

\section{Histopathological studies:}

The previous biochemical and physiological results were confirmed by histopathological alterations where clear damage of gills, liver and kidneys of the Nile tilapia; Oreochromis niloticus collected from the eastern and western sites of the lake in comparison with that collected from El-Boughaz inlet.

\section{Gills:}

The gills of Oreochromis niloticus collected from El-Boughaz inlet are formed of four gill arches on either side of the head and protected externally by the operculum. Each gill arch consists of two hemi-branchs and each hemibranch is composed of a row of long thin gill filaments (primary gill lamellae). Both sides of each gill filament bear numerous secondary gill lamellae which are the actual site of gas exchange. These lamellae are composed of a thin epithelial cell layer covering pillar cells which, in turn surround the blood sinusoids. At intervals along the layer of epithelial cells there were chloride cells and numerous mucus cells.

Gill sections of fish collected from the different studied sites are shown in photomicrograph (1). Gills of fish collected from the western and eastern sectors of the lake showed clear damage and histopathological changes which include necrosis of epithelial cells, epithelial hyperplasia with ballooning degeneration and desquamation of the epithelium. These changes are similar to that recorded by Pelgrom et al. (1995) who revealed that this effect is generally ascribed to structural and functional damage to the gills as a result of heavy metals accumulation which caused damage to gill epithelium, hypertrophy and hyperplasia of the gill epithelium and ultimately destroying the permeability characteristics of the cells.

\section{Liver:}

Histologically, the liver of Oreochromis niloticus collected from ElBoughaz inlet differs from that of mammals where there is no certain lobular pattern. However, the hepatic parenchyma is arranged radially around the central veins and blood sinusoids are irregularly distributed in the liver tissue. Hepatic cells are polygonal in shape and posses a central spherical or oval nucleus with prominent nucleolus. The nuclei appeared large, and exhibited noticeable variation in diameter from cell to cell.

Liver sections of fish collected from the different studied sites along ElBurullus lake are shown in photomicrograph (2). Liver sections of fish collected from the eastern and western sectors of the lake showed marked histopathological changes with special parenchymal cells and disintegration and necrosis of hepatic cells. The histopathological changes observed in the liver of 
Oreochromis niloticus are similar to that recorded in Channa punctatus exposed to $37 \mathrm{mg} \mathrm{Zn/l} \mathrm{for} 12 \mathrm{hrs}$ (Khangarot and Durve, 1982).

\section{Kidneys:}

The kidney of the fish collected from El-Boughaz inlet was characterized by renal tubules surrounded by haemopoietic tissue. Also, glomeruli and renal blood vessels were found between the renal tubules

Kidney sections of fish collected from the different studied sites along ElBurullus lake are shown in photomicrograph (3). Sections of kidney of fish collected from the eastern and western sectors of the lake declared a progressive damage of kidney tubules associated with tubular necrosis, injury of the wall of renal blood vessels and depletion of haemopoietic tissue. These observed alterations included damage of the kidney tubules associated with tubular necrosis, injury of the wall of renal blood vessels and depletion of haemopoietic tissues. These symptoms are in agreement with that observed by Sorensen (1991) and Zaghloul (2000).

In conclusion the results highlights spots on the serious effects of industrial and agricultural effluents on one of the main natural water resource in Egypt, El-Burullus lake especially at the eastern and western sectors. These serious effects could affect fish quality and hence become threat to man.

\section{REFERENCES}

Ablett, R. F; Sinnhuber, R. O. and Selivonchick, D. P. (1981). The effect of bovine insulin on $\left({ }^{14} \mathrm{C}\right)$ glucose and $\left({ }^{3} \mathrm{H}\right)$ leucine incorporation in fed and fates rainbow trout salmo gairdneri. Gen.Comp.Endocrinol., 44: 418-427.

Aldrin, J.f.; Messager, G.L. and Baudin Laurencin, F. (1982). La biochemie clinique en aquaculture. Interest et prespectives. Cnexo. Actes. Colloq., 14: 291-326.

AOAC (Association of Official Analytical Chemists) (1980). Official Methods of Analysis $.12^{\text {th }}$ edition, Washington, D.C.

APHA (American Public Health Association). American Water Works Association and Water Pollution Control Federation. (1995). Standard Methods for the Examination of Water and Wastewater. $19^{\text {th }}$ edition, New York, N.Y.

Barham, D. and Trinder, P. (1972). Enzymatic determination of Uric acid. Analyst, 97: 142-145. 
Carleton, M.; Drary, Y.; Wallington, E.A. and Cammeron, H. (1967). Carleton's Histological Technique, 4 th ed., Oxford Univ. Press, New Yourk , Toronto.

Carvalho ,C.S. and Fernandes , M.N. (2006). Effect of temperature on copper toxicity and hematological responses in the neotropical fish; prochilodus scrofa at low and high pH. Aquaculture, (251): 109- 117.

Caulton, M.S. (1982). Feeding, metabolism and growth of tilapias (ed.) By RSV pullin and RH lowe-McConnel.pp 157-180.

Clark, E.R. and Fraser, J.A.L. (1983). The survival and growth of six species of freshwater fish, in tap water and diluted and undiluted effluents from sewage percolating filters.J.Fish Biol., (22): 431-445.

Dethloff, G.M.; Schlenk, D.; Khan, S. and Bailey, H.C. (1999). The effects of copper on blood and biochemical parameters of rainbow trout (Oncorhynchus mykiss ). Arch. Environ. Contam. Toxicol., (36):415423.

Elghobashy, A.H.; Zaghloul, K.H. and Metwally. M.A. (2001): Effect of some water pollutants on the Nile tilapia; Oreochromis niloticus collected from the river Nile and some Egyptian Lakes.Egypt.J.Aquat. Biol. Fish., 5(4): 251- 279.

El-Naggar, G. O.; Zaghlol,K. H. ; Salah El-Deen, M.A. and Abo-Hegab, S.(1998). Studies on the effect of industrial water pollution along different sites of the River Nile on some physiological and biochemical parameters of the Nile tilapia, Oreochromis niloticus. $4^{\text {th }}$ Vet.Med.Zag.Congress (26-28 August 1998 in Hurghada): 713-735.

El-Sayed, A. M; El-Gobahy, A. and Al- Amoudi, M.( 1996). Effect of pond depth and water temperature on the growth, mortality and body composition of the Nile tilapia; Oreochromis niloticus ( L ). Aquacul.Res., (27): 681- 687.

FAO. (1992). Committee for Inland Fisheries of Africa. Report of the third session of the working Party on Pollution and Fisheries. Accra, Ghana, 25-29 November 1991. FAO Fisheries Report. No. 471. Rome, FAO. 1992. 43 p.

Gaber, H.S. (2003). Histopathological changes in liver of Tilapia zillii induced by aromatic hydrocarbons. J.Egypt. Ger. Soc.Zool., 42( C): 145-154. 
Gad, N. Sh. (2005). Impact of environmental pollution in the southern region of lake Manzalah Egypt on some biochemical parameters of Tilapia zillii. J. Egypt. Ger. Soc. Zool., 48 (A): 279 - 298.

Ghazaly, K.S. and Said, K.M. (1995). Physiological characteristics of Tilapia nilotica under acute stress of copper. J. Egypt. Ger.Soc.Zool.,16(A): 287-301

Glubokov, A.I. (1990). Growth of three species of fish during early ontogeny under normal and toxic conditions.J.Vopr. Ikhtiol., 30(1): 137- 143.

Gluth, G. and Hanke, W. (1985). A comparison of physiological changes in crap, Cyprinus carpio induced by several pollutants of sublethal concentrations. I- The dependency on exposure time. Ecotoxicol. Environ. Safety, 9: 179- 188.

Grosell, M. and Wood, C.M. (2002). Copper uptake across rainbow trout gills: mechanisms of apical entry J Exp Biol.,(205):1179-1188.

Grosell, M.; McDonald, M.D.; Wood, C.M. and Walsh, P.J. (2004). Effects of prolonged coper exposure in the marine gulf toadfish (Opsanus beta). I. Hydromineral balance and plasma nitrogenous waste products. Aquat Toxicol. (68): 249- 262.

Gupta, P.K.(1977). Haematological Techniques. $4^{\text {th }}$ ed. Syndicate, India, pp. 231.

Haggag, A.M.; Marie, M.A.S. and Zaghloul, K.H. (1999). Seasonal effects of the industrial effluents on the Nile catfish; Clarias gariepinus. J. Egypt. Ger. Soc. Zool., 28(A): 365-391.

Heath, A.G. (1995). Water Pollution and Fish Physiology. CRC. Press. Inc. Boca Raton, Florida. 359pp.

Henry , R.J.(1974). Clinical chemistry, principles and techniques .2 ${ }^{\text {nd }}$ edition, Harper and Row., pp.525.

Hesser, E. F. (1960). Methods for routine fish haematology. Prog. Fish cult., 22: $164-171$. 
Hinton, D. E.; Klauning, J. E. and Lipsky, M. M. (1978). PCB- induced alternations in teleost liver: a modle for environmental disease in fish. Mar. Fish. Rev., (40): 47- 50.

Joslyn, M.A.(1950). Methods in food Analysis. Chapter 20, Academic Press, New York.

Khangarot, B.S. and Durve, V.S. (1982). Note on the acute toxicity of zinc and the interactions of zinc and nickel to a freshwater teleost; Channa punctatus (Bloch). Indian. J. Anim. Sci., 52(8): 722-725.

Kheir, M.T.; Mechail, M.M. and Abo-Hegab, S. (1998a). Some biochemical changes of Oreochromis niloticus reared at different saline concentrations. Egypt J Zool., 30: 117- 129.

Kheir, M.T.; Mechail, M.M. and Abo-Hegab, S. (1998b). Growth of adult and newly hatched fry of Oreochromis niloticus reared at different saline concentrations. Egypt J Zool. 30: 107- 115.

King, E.J. and Wootton, I.D.P.(1959). Determination of total protein. Micro_analysis in Medical Biochemistry, Churchill, London.

Lockhart, W.L. and Metnar, D. A. ( 1984). Fish serum chemistry as a pathology tol. Fisher., 16: 73- 86.

Maita, M.; Shiomitsu, K. and Ikeda, Y.(1984). Health assessment by the climogram of hemochemical constituents in cultured yellow tail. Bull. Jap. Soc. Scient., 51: 205-211.

Malla Reddy, P. and Bashamohideen, M. D. ( 1995). Alternations in protein metabolism in selected tissues of fish Cyprinus carpio during sublethal concentration of cypermethrin. Environ. Monit. Assess., 36: 183- 190.

Mansour, S.A. and Sidky, M .(2002). Ecotoxicology Studies . 3 . Heavy metals contaminating water and fish from fayoum Governorate, Egypt . Food Chemistry, 78:15-22.

Marie, M.A.S. (1990). Effect of sublethal concentration of zinc on blood parameters of the Nile catfish; Clarias lazera. Proc. Zool. Soc. A.R.Egypt, 18: 413-429. 
Maxine, M. and Benjamine, B.S. (1985. Outline of Veterinary Clinical Pathology. $3^{\text {rd }}$ edit, Colorado State University. Printed in India at Rehka printers PVT. LTD., New Delhi- 110020.

Mazeaud, M.M.; Mazeaud, F. and Donaldson, E.M. (1977). Primary and secondary effects of stress in fish, some new data with a general review. Trans. Am. Fish. Soc., 106: 201-207.

Mazon, A. F.; Monteiro, E. A. S.; Pinheiro, G. H. D. and Fernandes, M. N. (2002). Gill cellular changes induced by copper exposure in the South American tropical freshwater fish Prochilodus scrofa. Environm. Res. A., 88: 52- 63.

McCarter, J. A. and Roch, M ( 1984). Chronic exposure of coho salmon to sublethal concentrations of copper. III. Kinetics of metabolism of metallothionein. Comp. Biochem. Physiol., 79 (C): 83- 87.

Mommsen, T. P. and Walsh, P. J. (1989). Evolution of urea synthesis in vertebrates the piscine connection. Sci., 243: 72- 75.

Nagdi, A.Z. and Shaker, N. I. (1998). Effect of water sources on some microelements in fish farm. Egypt.J.Agric.Res.,76(1): 351-357.

National Water Resources Plan for Egypt. (2000), Ministry of water Resources and Irrigation, Egypt. Planning sector (NWRP). Fisheries and Water Resources.

Nussy, G.; Van Vuren, J. H. J. and Du preez, H.H. (1995a). Effect of copper on haematology and osmoregulation of the Mozmbique tilapia; Oreochromis mossambicus (Cichlidae). Comp.Biochem. Physiol., 111(c): 369- 380.

Nussy, G.; Van Vuren, J. H. J. and Du preez, H.H. (1995b). Effect of copper on differential white blood cell counts of the Mozmbique tilapia Oreochromis mossambicus (Cichlidae). Comp.Biochem. Physiol 111(c): 381- 388.

Oikari, A. and Soivio, A.(1977). Physiological condition of fish exposed to water containing pulp and paper industry wastes and sewage. In "Biological Monitoring of Inland Fisheries" (Alabaster, J.S.,ed), Applied Science, London, pp, 89-96. 
Paris- Palacios, S. ; Biagienti- Risbourg, S. and vernet, G. (2000). Biochemical and (ultra) structural hepatic perturbations of Brachydanio rerio ( teleostei, Cyprinidae) exposed to two sublethal concentrations of copper sulfate: Aquatic Toxicol., 50: 109- 124.

Pelgrom, S. M. ; Lamers, L. ; Loch, R. A. C. ; Balm, P. H. M. and Wendelaar Bonga,S. E. (1995). Integrated physiological response of tilapia; Oreochromis mossambicus to sublethal copper exposure. Aquat. Toxicol., 32: 303- 320.

Pickering, A.D.(1981). Stress and compensation in teleostean fishes. Response to social and physical factors. In: "Stress and Fish" (Pickering, A. D. ed.). Academic Press, New York, London, pp. 295-322.

Reader, J. P; Everall, N. C; Sayer, M. D. J. and Morris, R. (1989). The effect of eight trace metals in acid soft water on survival, mineral uptake and skeletal calcium deposition in yolk- sac fry of brown trout; Salmo trutta L. J. Fish Biol., 35: 187 -197.

Reitmans, S. and Frankel,S.(1957). A colorimetric method for the determination of serum glutamic oxaloacetic and glutamic pyruvic transaminases. Am.J.clin.Pathol., 28: 53-56 .

Salah El-Deen, M.A.; Zaghloul, K. H. ; El-Naggar ,G.O. and Abo-Hegab, S. (1999). Concentrations of heavy metals in water, sediment and fish in the River Nile in the industrial area of Helwan. Egypt. J. Zool., 32: 373-395.

Salama, E.S.N (1995). Histopathological, histochemical and electron microscopic studies on a sewage polluted freshwater fish. Ph.D. Thesis, Zool.Dept., Fac. Sci., Zagazig Univ., Egypt.

Sandnes , K.; Lie, Q. and Waagbq, R. (1988). Normal ranges of some blood chemistry parameters in adult farmed Atlantic salmon; Salmo salar. J. Fish Biol., 32: $129-136$.

S.A.S. (2000). Statistical Analyses System, Version 6.2.

Schmit, J.M. (1964). Determination of total lipid (Lipides-kit), Lyon.

Schreck ,C. B. and Moyle, P. B. (1990). Method of fish Biology . American Fisheries Society, Bethesda, Mavyland, USA. 
Shaaban, M.T.; Khallaf, E.A.H.; Nagdy, Z.A. and El-Gammal, M.A. (1999). Variation of biological dynamics and physicochemical fluctuations, in water of fish ponds due to different (organic and inorganic) fertilizers applications. $6^{\text {th }}$ International Conference of Union Arab Biologists, 8(B): 293-313.

Shenouda, T.S.; Abou-Ziad, F.A.;Al-Assuity,A.I. and Abada A.E.(1992). Water pollution and bioaccumulation of the highly pollutant agents in different organs of Oreochromis niloticus, near Kafr El-Zayat. Proc. Zool.Soc. A.R.E., 23 (2):12-25.

Sidwell, V.D.; Stillings,B.R. and Knoble ; G.M. (1970). The fish protein concentration .10_Nutritional quality and using fish In foods. J. Food.Technol., 14: 40-46.

Sorensen, E.M.(1991). "Metal poisoning in fish." Austin, Texas. CRC press Inc., Boston.

Swift, D.J. (1981). A holding box system for physiological experiment on rainbow trout (Salmo gairdneri Rich.) requiring rapid blood sampling. Fish. Biol., 18: 309-319.

Trinder, P.(1969). Enzymatic colorimetric method of glucose. Ann .Clin Biochem ., 6:24.

Van Kampen, E.J. and Zijlstra, N.C. (1961). Determination of haemoglobin. Clin. Chem. Acta., 5: 719-720.

Weatherley, A.H. and Gill, H.S. (1983). Relative growth of tissues at different somatic growth rates in rainbow trout; Salmo gairdneri Richardson. J. Fish Biol., 22: 43-60.

Weatherley, A.H. and Gill, H.S. (1987). Tissues and growth. In"The biology of Fish Growth". St. Edmundsbury Press, Great Britain. Pp. 147- 173.

White, A. and Fletcher, T.C. (1985). Serum changes in serum glucose and condition of the plaice; Pleuronectes platessa. J. Fish Biol., 26:755764.

WHO, World Health Organization (1989). Guide lines for drinking water. Geneva. 
Woo, N.Y.S.; Ng, T.B.; Leung, T.C. and Chow, C.Y. (1997). Enhancement of growth of tilapia; Oreochromis niloticus in iso-osmotic medium. J. Appl. Ichthyol., 13: 67-71.

Yilmaz ,F. ; Ozdemir , N .; Demirak , A . and Tuna , A . L . (2007). Heavy metal levels in two fish species; Leucisws cephalus and lepomis gibbosus . Food Chem., 100(2) :830-835.

Zaghloul, K.H. (2000). Effect of different water sources on some biological and biochemical aspects of the Nile tilapia; Oreochromis niloticus and the Nile catfish; Clarias gariepinus.

Zaghloul, K.H. (2001). Usage of zinc and calcium in inhibiting the toxic effect of copper on the Afriac catfish; Clarias gariepinus. J Egypt Ger Sco Zool. 35(C): 99- 120.

Zaghloul, K.H.; Omar, W. A.; Azer, W. Z. and Abo-Hegab, S. 2000). Ecological and Biochemical studies on the Nile fish; Oreochromis niloticus cultured in different aquatic habitats. Egypt. J. Zool., 34: 379 - 409.

Zaghloul, K.H.; Omar, W.A. and Abo-Hegab, S. (2005). Environmental hazard risk assessment on; Oreochromis niloticus and Tilapia zilli fsh. J. Egypt. Ger. Sco. Zool., 46(A): 105- 139. 

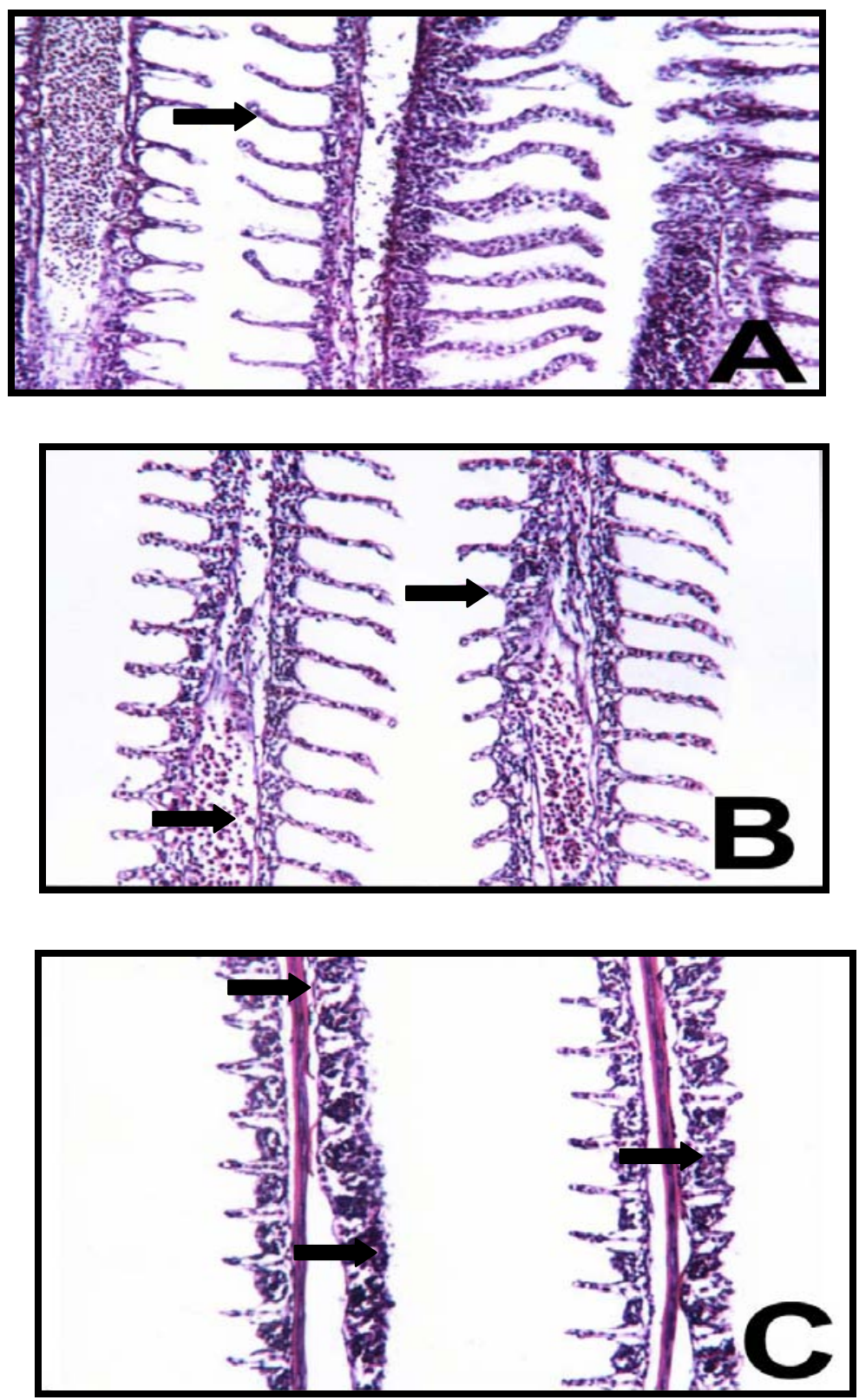

Photomicrograph (1):

Histological sections in gills of Oreochromis niloticus collected from different studied sites along Lake Burullus.

A: El-Boughaz inlet (Site 1)

B: Industrial and agricultural effluents (Site3) eastern sector.

C:Agricultural effluents (Site2) western sector.

Stain and Magnification: (H \& E) X 400. 

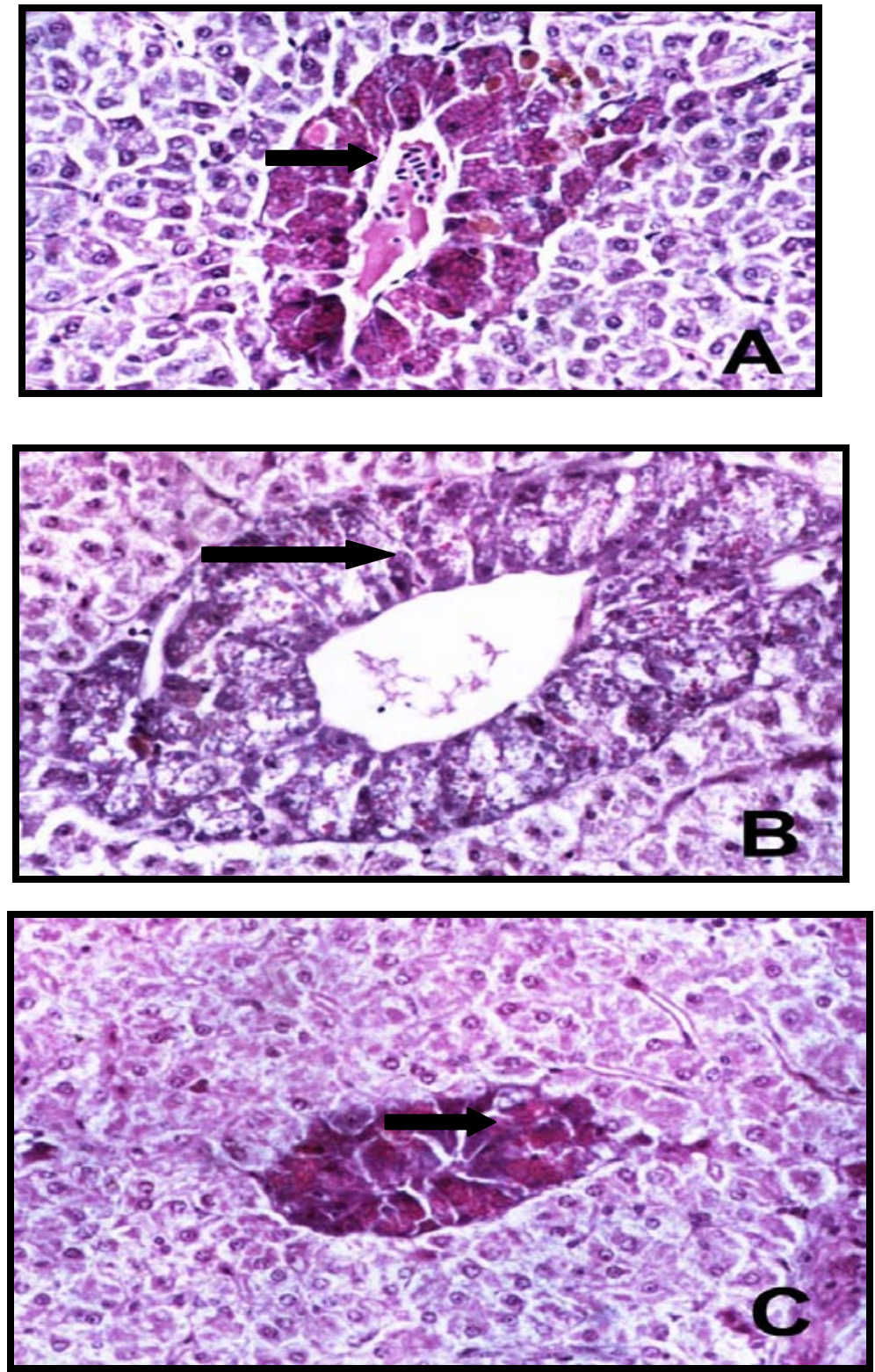

\section{Photomicrograph (2):}

Histological sections in liver of Oreochromis niloticus collected from different studied sites along Lake Burullus.

A: El-Boughaz inlet (Site1)

B: Industrial and agricultural effluents (Site3) eastern sector.

C:Agricultural effluents (Site2) western sector. 

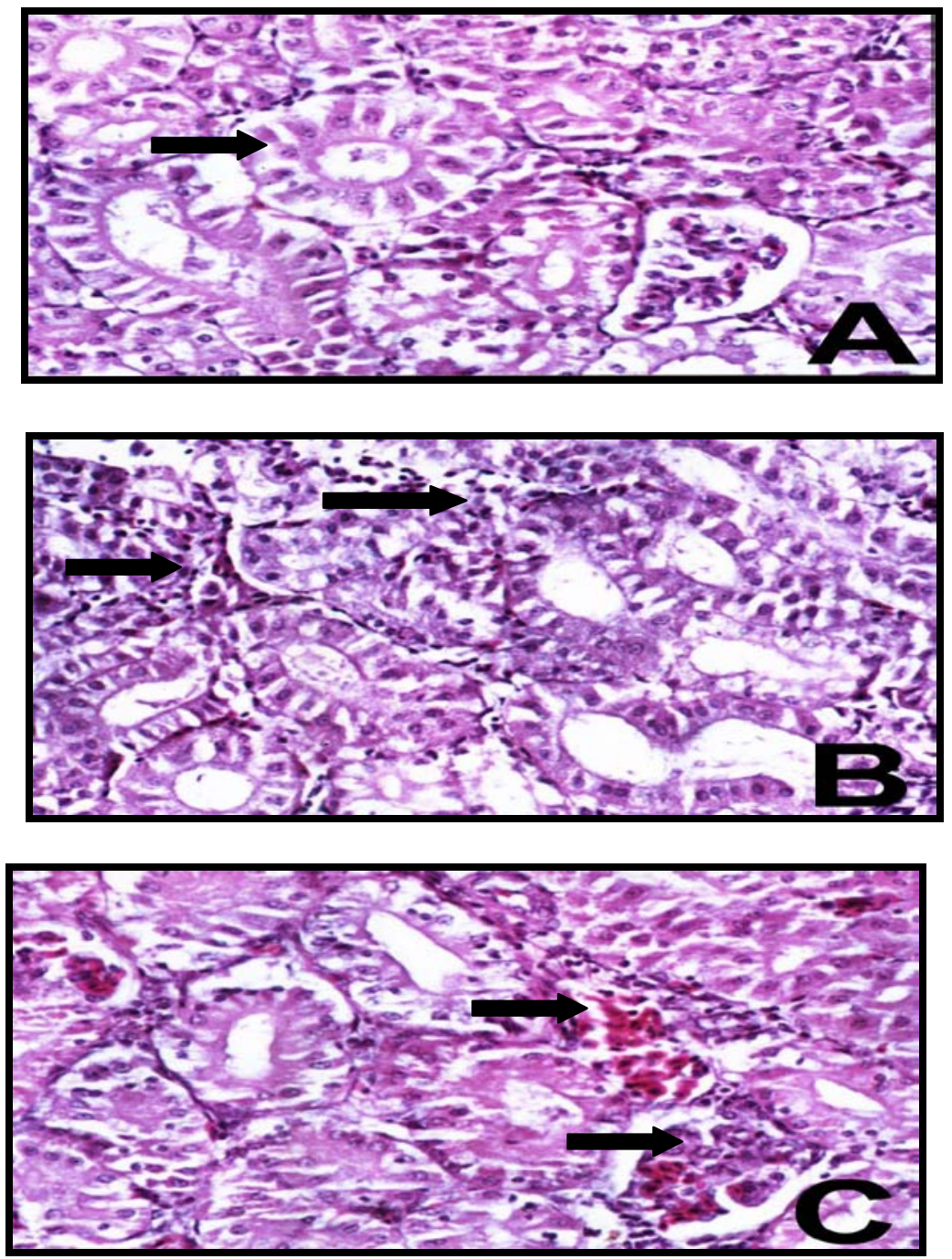

\section{Photomicrograph (3):}

Histological sections in kidney of Oreochromis niloticus collected from different studied sites along Lake Burullus.

A: El-Boughaz inlet (Site1)

B: Agricultural effluents (Site2) western sector.

C: Industrial and agricultural effluents (Site3) eastern sector.

Stain and Magnification: (H \& E) X 400. 